\title{
Sistem Informasi Penjadwalan Petugas Ibadah Dan Kehadiran Jemaat Sektor 3 di Gereja Hebron Protestan Samarinda
}

\author{
Veronaldo Yoga Saputra \\ Politeknik Pertanian Negeri \\ Samarinda \\ Teknologi Rekayasa Perangkat \\ Lunak \\ Manajemen Pertanian \\ Samarinda, Indonesia \\ y.vero1102@gmail.com
}

\author{
Yulianto \\ Politeknik Pertanian Negeri \\ Samarinda \\ Teknologi Rekayasa Perangkat Lunak \\ Manajemen Pertanian \\ Samarinda, Indonesia \\ Yulianto.tile@yahoo.com
}

\author{
Erina Hertianti \\ Politeknik Pertanian Negeri \\ Samarinda \\ Teknologi Rekayasa Perangkat Lunak \\ Manajemen Pertanian \\ Samarinda, Indonesia \\ erina_nugroho@yahoo.com
}

\begin{abstract}
Abstrak - Veronaldo Yoga Saputra Pembuatan aplikasi ini dilatarbelakangi oleh belum maksimalnya penjadwalan ibadah, khususnya dalam penjadwalan ibadah saat ini yang masih manual dengan buku yang bernama warta jemaat yang di dapatkan usai melakukan ibadah minggu, dari jemaat yang kurang mendapatkan informasi tersebut, aplikasi ini bisa memudahkan jemaat untuk mengetahui jadwal ibadah dengan sangat mudah. Tujuan dalam skripsi ini adalah merancang dan membuat aplikasi sistem yang dapat digunakan untuk memudahkan jemaat melihat jadwal ibadah sektor 3 dan merancang suatu sistem berbasis web yang dapat dimengerti dengan mudah oleh jemaat. Hasil dari penelitian ini adalah memudahkan jemaat sektor 3 untuk melihat jadwal ibadah secara online.
\end{abstract}

Kata Kunci- data jemaat gereja, laravel.

\section{PENDAHULUAN}

Pengertian teknologi informasi secara umum ialah suatu studi perancangan, implementasi, pengembangan, dukungan atau manajemen sistem informasi berbasis komputer terutama pada aplikasi hardware (perangkat1. keras) dan software (perangkat lunak komputer).

Secara sederhana, pengertian teknologi informasi adalah fasilitas-fasilitas yang terdiri dari2. perangkat keras dan perangkat lunak dalam mendukung dan meningkatkan kualitas informasi untuk setiap lapisan masyarakat secara cepat dan berkualitas (Kemala, 2019).

Contohnya pada Gereja Hebron Protestan (GHP) Samarinda Seberang merupakan salah satu organisasi keagamaan yang memiliki data yang cukup banyak seperti data jemaat, Dan data pelayan. Gereja Hebron Protestan (GHP) Samarinda Seberang saat ini belum memiliki sistem informasi yang baik sehingga seringkali mendapatkan kesulitan dalam pengelolaan jadwal ibadah. Dalam pengelolahan jadwal ibadah yang tidak lain dapat disebut juga sebagai kebaktian, kebaktian tersebut terdiri dari beberapa kaum yaitu PKB (Persekutuan Kaum Bapa), PKP (Persekutuan Kaum Perempuan), GP (Gerakan Pemuda), dan PKLU (Persekutuan Kaum Lanjut Usia).
Sistem yang berjalan saat ini memungkinkan hilangnya dan rusaknya data di Gereja Hebron Protestan (GHP) Samarinda Seberang karena penyimpanan yang kurang baik dan terjamin. Begitu juga dengan data pelayan yang bisa juga disebut sebagai data Pengurus gereja, ternyata belum mempunya sistem informasi dalam riwayat pelayannya yang sedang atau sudah pernah melayani di gereja sebagai arsip dokumen gereja. Sehingga pengurus dapat mengetahui siapa saja anggota yang pernah menjadi pengurus gereja dan melayani di kebaktian tersebut.

Dikarenakan data gereja sangat banyak dan data gereja ini sangat penting bagi perkembangan gereja maka diperlukan suatu sistem penjadwalan petugas ibadah sektor 3 yang aman dengan memberikan kemudahan kepada pengguna dalam mengakses sistem informasi penjadwalan ibadah sektor 3. Ditinjau dari permasalahan yang ada tersebut, maka perlu dibuat suatu sistem informasi penjadwalan petugas ibadah sektor 3 di Gereja Hebron Protestan (GHP) Samarinda Seberang yang terkomputerisasi dan moderen. ini adalah:

Adapun maksud dan tujuan dari pembuatan skripsi

Tujuan dalam skripsi ini adalah merancang dan membuat aplikasi sistem yang dapat digunakan untuk memudahkan jemaat melihat jadwal ibadah sektor 3 .

Merancang suatu sistem berbasis web yang dapat dimengerti dengan mudah oleh jemaat.

Manfaat dari aplikasi ini adalah dapat membantu jemaat sektor 3 untuk melihat jadwal ibadah secara online.

\section{TINJAUAN PUSTAKA}

\section{A. Kajian Ilmiah}

Beberapa studi literatur yang digunakan sebagai pedoman pembuatan skripsi ini adalah sebagai berikut:

Penelitian yang dilakukan oleh (Anindya, 2017), berjudul Perancangan Sistem Informasi Tempat Ibadah Beragam Agama Di Kota Solo. Aplikasi ini bertujuan untuk memudahkan masyarakat untuk mencari informasi tempat ibadah sesuai agama masing-masing. Sistem 
informasi ini hanya mencakup alamat lengkap beserta foto dan agenda kegiatan rutin untuk memudahkan ketika seseorang ingin mencari informasi tentang kegiatan harian tempat ibadah tersebut dengan lebih mudah, cepat dan efisien. Website ini juga dapat memudahkan para pengurus tempat ibadah untuk menyebar luaskan informasi yang ada pada tempat ibadah mereka masingmasing. Pengujian sistem dilakukan dengan metode kuisioner. Dari hasil kuisioner yang disebar kepada 30 responden, teks didalam website mudah dibaca dan dipahami mendapatkan persentase paling tinggi yang berarti website ini cukup mudah dipahami untuk user. Persentase paling rendah adalah dalam hal perlu dikembangkannya menjadi aplikasi mobile karena Subjek penelitian atau responden sudah cukup puas jika hanya ditampilkan lewat website, tetapi tidak tertutup kemungkinan jika suatu saat sistem informasi ini dikembangkan menjadi aplikasi mobile karena di jaman sekarang hampir semua orang sudah memiliki ponsel.

Penelitian yang dilakukan oleh Sukarno (2017) berjudul Perancangan Situs Web Untuk Informasi Pelayanan Jemaat Gereja House of Filadelfia Di Jakarta Selatan.

Penelitian ini bertujuan untuk membantu bagian administrasi gereja dalam mengolah data gereja seperti; kegiatan jemaat, pendeta, keluarga, diakonia dan semua kegiatan yang akan dilakukan maupun sudah dilakukan, sehingga ketika akan melakukan penambahan, pencarian informasi seputar gereja dapat dilakukan dengan mudah, sehingga dapat meningkatkan kualitas pelayanan gereja House of Filadelfia, memudahkan jemaat untuk mengetahui segala informasi yang dilakukan oleh pimpinan gereja. Maka dari itu penulis mengambil judul "Sistem Informasi Pelayanan Jemaat Gereja House of Filadelfia berbasis Website".

Penelitian yang dilakukan oleh (Adhi, 2017). Berjudul Sistem Informasi Penjadwalan Pelatihan Divisi Training Seamolec Berbasis Web. Penelitian ini bertujuan untuk mengelola jadwal pelatihan masih manual seperti pencatatan jadwal pelatihan serta pemilihan data staff yang akan mengisi pelatihan di papan tulis dan penyampaian informasi melalui sosial media. Merancang dan mengembangkan sistem informasi ini dibutuhkan beberapa fitur seperti cetak kegiatan pelatihan dan cetak jadwal pelatihan untuk memudahkan manajer menyampaikan informasi pelatihan kepada staff dan organisasi. Implementasi dari Sistem Informasi Penjadwalan Pelatihan Divisi Training SEAMOLEC Berbasis Web ini adalah dengan memanfaatkan teknologi internet yang akan memberikan memudahkan manajer dalam mengelola jadwal pelatihan dimanapun dan kapanpun sehingga informasi dapat dengan cepat tersampaikan.

Berdasarkan penelitian yang dilakukan sebelumnya, maka penelitian dengan judul Sisten Informasi Penjadwalan dan Data Pengunjung Ibadah di Gereja Hebron Protestan Samarinda dan ini akan dibuat dengan berbasis web untuk menjadi sebuah aplikasi berbasis Web sebagai sistem keamanannya. Daftar kajian ilmiah dapat di lihat pada tabel 1 .
Tabel 1. Daftar Kajian Ilmiah

\begin{tabular}{|c|c|c|c|}
\hline No. & Nama & Judul & Tahun \\
\hline 1 & $\begin{array}{c}\text { Anindya Difa } \\
\text { Novitasari }\end{array}$ & $\begin{array}{c}\text { Perancangan Sistem } \\
\text { Informasi Tempat } \\
\text { Ibadah Beragam } \\
\text { Agama Di Kota Solo. }\end{array}$ & 2017 \\
\hline 2 & $\begin{array}{l}\text { Sukarno Bahat } \\
\text { Nauli dan } \\
\text { Musa }\end{array}$ & $\begin{array}{l}\text { Perancangan Situs Web } \\
\text { Untuk Informasi } \\
\text { Pelayanan Jemaat } \\
\text { Gereja House of } \\
\text { Filadelfia Di Jakarta } \\
\text { Selatan. }\end{array}$ & 2017 \\
\hline 3 & $\begin{array}{l}\text { Adhi Ircham } \\
\text { Ardhiansyah } \\
\text { dan Mamay } \\
\text { Syani }\end{array}$ & $\begin{array}{c}\text { Sistem Informasi } \\
\text { Penjadwalan Pelatihan } \\
\text { Divisi Training } \\
\text { Seamolec Berbasis } \\
\text { Web. }\end{array}$ & 2017 \\
\hline 4 & $\begin{array}{c}\text { Veronaldo } \\
\text { Yoga Saputra }\end{array}$ & $\begin{array}{c}\text { Sisten Informasi } \\
\text { Penjadwalan dan Data } \\
\text { Pengunjung Ibadah di } \\
\text { Gereja Hebron } \\
\text { Protestan Samarinda }\end{array}$ & 2018 \\
\hline
\end{tabular}

\section{B. Landasan Teori}

\section{Data Flow Diagram}

Data Flow Diagram atau sering disingkat DFD adalah perangkat-perangkat analisis dan perancangan yang terstruktur sehingga memungkinkan peng-analis sistem memahami sistem dan subsistem secara visual sebagai suatu rangkaian aliran data yang saling berkaitan.

Aliran data merupakan perpindahan data dari satu titik ke titik yang lain penggambarannya dengan cara kepala tanda panah mengarah ke tujuan datanya. Proses biasanya selalu menunjukkan suatu perubahan data dan terjadinya proses transformasi data, penyimpanan Data (data store) diberi nama dengan kata benda, sesuai dengan data yang disimpan didalamnya.

Didalam DFD terdapat 3 level, yaitu:

1. Diagram Konteks menggambarkan satu lingkaran besar yang dapat mewakili seluruh proses yang terdapat di dalam suatu sistem. Merupakan tingkatan tertinggi dalam DFD dan biasanya diberi nomor 0 (nol). Semua entitas eksternal yang ditunjukkan pada diagram konteks berikut aliran-aliran data utama menuju dan dari system diagram ini sama sekali tidak memuat penyimpanan data dan tampak sederhana untuk diciptakan.

2. Diagram Nol (diagram level-1) merupakan satu lingkaran besar yang mewakili lingkaran-lingkaran kecil yang ada di dalamnya. Merupakan pemecahan dari diagram Konteks ke diagram Nol. di dalam diagram ini memuat penyimpanan data.

3. Diagram Rinci merupakan diagram yang menguraikan proses apa yang ada dalam diagram Nol.

Fungsi dari Data Flow Diagram adalah alat pembuatan model yang memungkinkan profesional sistem untuk menggambarkan sistem sebagai suatu 
jaringan proses fungsional yang dihubungkan satu sama lain dengan alur data, baik secara manual maupun komputerisasi. DFD ini adalah salah satu alat pembuatan model yang sering digunakan, khususnya bila fungsifungsi sistem merupakan bagian yang lebih penting dan kompleks dari pada data yang dimanipulasi oleh sistem. Dengan kata lain, DFD adalah alat pembuatan model yang memberikan penekanan hanya pada fungsi sistem. DFD ini merupakan alat perancangan sistem yang berorientasi pada alur data dengan konsep dekomposisi dapat digunakan untuk penggambaran analisa maupun rancangan sistem yang mudah dikomunikasikan oleh profesional sistem kepada pemakai maupun pembuat program (Jenius, 2012)

\section{Sistem Informasi}

Sistem informasi yaitu suatu sistem yang menyediakan informasi untuk manajemen dalam mengambil keputusan dan juga untuk menjalankan operasional perusahaan, di mana sistem tersebut merupakan kombinasi dari orang-orang, teknologi informasi dan prosedur-prosedur yang tergorganisasi, biasanya suatu perusahan atau badan usaha menyediakan semacam informasi yang berguna bagi manajemen. Sebagai contoh: Perusahaan toko buku mempunyai sistem informasi yang menyediakan informasi penjualan buku-buku setiap harinya, serta stock buku-buku yang tersedia, dengan informasi tersebut, seorang manajer bisa membuat kebutusan, stock buku apa yang harus segera mereka sediakan untuk toko buku mereka, manajer juga bisa tahu buku apa yang paling laris dibeli konsumen, sehingga mereka bisa memutuskan buku tersebut jumlah stocknya lebih banyak dari buku lainnya (Dimas, 2013).

\section{PHP}

PHP merupakan singkatan dari Personal Home Page yang digunakan untuk membuat situs pribadi. Namun seiring perkembangannya, akronim Personal Home Page diperbaharui. Personal Home Page sendiri bermula ketika Rasmus Lerdorf, seorang pemrogram di Denmark/GreenLand pada 1994 membuat script dengan bahasa Perl di web pribadinya, bagi Anda yang berkecimpung di dunia desain web mungkin tidak asing lagi mendengar kata PHP, Definisi dari PHP adalah bahasa pemrograman server-side yang dirancang untuk pengembangan web. PHP dikatakan server-side karena program yang diberikan akan dijalankan/diproses pada komputer yang bertindak sebagai server. Sebagai contoh, ketika Anda membuka situs facebook.com maka web browser akan melakukan request ke server (Syafitri, 2019).

\section{Laravel}

Laravel adalah sebuah framework PHP yang dirilis dibawah lisensi MIT, dibangun dengan konsep MVC (model view controller). Laravel adalah pengembangan website berbasis MVP yang ditulis dalam PHP yang dirancang untuk meningkatkan kualitas perangkat lunak dengan mengurangi biaya pengembangan awal dan biaya pemeliharaan, dan untuk meningkatkan pengalaman bekerja dengan aplikasi dengan menyediakan sintaks yang ekspresif, jelas dan menghemat waktu. MVC adalah sebuah pendekatan perangkat lunak yang memisahkan aplikasi logika dari presentasi. MVC memisahkan aplikasi berdasarkan komponen- komponen aplikasi, seperti: manipulasi data, controller, dan user interface (Ica, 2019).

\section{Liturgos}

Dalam beberapa tahun belakangan ini di dalam ibadah-ibadah di kalangan Kristen di Indonesia diperkenalkan dengan sebuah istilah baru "liturgos" yang konon dimunculkan dalam bahasa Indonesia sebagai koreksi atas kata "liturgis". Hingga kini di berbagai gereja dijumpai sejumlah ketidaksepahaman apakah kata "liturgis" atau "liturgos" yang lebih tepat dipakai. Untuk menghindari perdebatan ini, ada yang mengambil jalan tengah dengan menggunakan istilah "pemimpin liturgi" atau "worship leader" atau "MC". Walaupun telah diperkenalkan berbagai istilah untuk menyebutkan fungsi seseorang yang memimpin jalannya kebaktian Minggu di gereja, keberadaan "liturgis" dan "liturgos" sebagai dua kata yang bersaing tetap perlu diselesaikan untuk menjelaskan duduk perkara kedua kata ini dan demi kejernihan pemahaman bersama.

Melalui tulisan ini diharapkan segenap umat Kristen yang berbahasa Indonesia dapat memahami dengan jelas asal-muasal kata ini dan bagaimana kata ini diserap ke dalam bahasa Indonesia. Lebih lanjut, diharapkan gerejagereja berbahasa Indonesia pun dapat menggunakan bahasa Indonesia dengan tepat sehingga melalui penggunaan ungkapanungkapan yang tepat iman jemaat dapat dibangun dengan lebih sistematis melalui setiap pesan yang diutarakan oleh gereja. Penggunaan istilahistilah lainnya yang begitu beragam seperti "pemimpin liturgi", "worship leader" dan "MC" akan mengundang diskusi tersendiri lagi baik mengenai kesetaraan di antara semua istilah tersebut maupun ketepatan maknanya. Karena itu, tulisan ini tidak akan membahas lebih jauh istilah-istilah lainnya ini (Andrea, 2006).

\section{Pelayan Firman}

Yang dimaksud Pelayan Tuhan adalah mereka yang mengambil bagian dalam karya pelayanan bagi Tuhan. Dengan pengertian ini maka yang dimaksud bukan hanya para pelayan sel atau para pemimpin dalam struktur KTM (Komunitas Tritunggal Mahakudus) tetapi semua yang biasa melayani, apakah itu dewan pengurus atau pelayan pujian penyembahan, pelayan doa, pelayan firman, dan lain-lain. Kenyataan bahwa banyak orang setelah mengalami pengalaman cinta Tuhan, lalu terdorong untuk mau mencintai Tuhan melalui pelayanan mereka. Tentu saja hal ini baik karena kepada setiap orang yang dibaptis, Tuhan memberikan kerinduan untuk berevangelisasi supaya pewartaan tetap berkesinambungan sampai akhir zaman. Demikian pula dalam KTM (Komunitas Tritunggal Mahakudus), evangelisasi merupakan salah satu tujuan seperti yang tertuang dalam visi dan misi KTM (Komunitas Tritunggal Mahakudus) bahwa setelah para anggota 
KTM (Komunitas Tritunggal Mahakudus) mengalami sendiri akan kehadiran Allah yang penuh kasih dan menyelamatkan, mereka juga akan menghantar orang lain kepada pengalaman yang sama. Akan tetapi, terkadang maksud baik untuk melayani ini tidak diiringi dengan kebijaksanaan untuk mengikuti kehendak dan rencana Tuhan dalam dirinya dan dalam komunitas karena kekurangmengertiannya. Akibatnya banyak pelayan Tuhan yang macet di tengah jalan ataupun mereka sendiri kekeringan sehingga akhirnya bukan mereka yang melayani tetapi justru mereka yang butuh dilayani. Kehendak baik atau perbuatan-perbuatan baik seseorang banyak sekali, tetapi bukan semua kehendak baik atau perbuatan baik itu sesuai dengan kehendak Tuhan.

Seorang pelayan Tuhan harus menyadari akan keterbatasannya, sehebat apapun ia, tidak akan dapat melakukan segala sesuatu yang dianggapnya baik dalam waktu bersamaan. Dalam hal ini seorang pelayan Tuhan butuh kerelaan untuk membagi-bagi pekerjaan dengan orang lain. Jika tidak, dia akan jatuh dalam bahaya kesombongan dan kerakusan rohani. Justru dengan membagi pekerjaan pelayanan kepada orang lain, akan ada banyak pekerjaan yang akan terselesaikan dan juga banyak ide dan kreasi akan muncul. Di lain pihak ada pelayan Tuhan yang tidak pandai memilah-milah mana yang perlu didahulukan dan mana yang kemudian. Untuk itu sangat perlu bagi seorang pelayan Tuhan untuk dengan bijaksana mengatur tingkatan-tingkatan prioritas di dalam hidupnya. Tingkatan prioritas ini dipengaruhi oleh tingkat kepentingan sesuai situasi dan kondisi, maka untuk itu mohonlah rahmat kebijaksanaan kepada Tuhan, yang akan banyak dibahas di sini adalah prioritas pertama seorang pelayan Tuhan (Giovanny, 2014).

\section{Sektor}

Sektor merupakan salah satu kalimat yang artinya menunjukan tempat atau wilayah sekitar ruang lingkup lingkungan kecil dari suatu wilayah.

8. MySQL

Istilah SQL dapat diartikan sebagai suatu bahasa yang digunakan untuk mengakses suatu data dalam database relasional dan terstruktur sedangkan MySQL dalam hal ini menjadi software atau tools untuk mengelola atau memanajemen SQL dengan menggunakan Query atau Bahasa khusus. Pada dasarnya database yang dikelola dalam MySQL memang tidak jauh berbeda dari Microsoft Acces yakni berbentuk tabel - tabel yang berisi informasi tertentu. Perbedaannya terletak pada penggunaan serta pengelolaan database tersebut. MySQL ini tergolong suatu software yang open source dan berlisensi GPL atau General Public License. Lisensi GPL ini hanya ditujukan pada perangkat lunak tertentu untuk keperluan proyek GNU, inilah yang menjadi faktor banyaknya pengguna MySQL di seluruh dunia. Selain mudah digunakan, anda dapat mengelola data dengan lebih efektif karena menggunakan script atau Bahasa tertentu dan secara otomatis akan menjadi perintah ke system (Hermawan, 2019).
Software yang satu ini bernama XAMPP yang merupakan singkatan dari Apache, MySQL, PHP dan Perl sedangkan huruf " $X$ " dimaksudkan sebagai suatu software yang dapat dijalankan di empat OS utama seperti Windows, Mac OS, Linux dan Solaris. Istilah ini seringkali disebut dengan cross platform (software multi OS). Sesuai dengan namanya software yang satu ini merupakan gabungan dari beberapa software dengan fungsi yang sama yakni menunjang para pembuat web yang menginginkan adanya web server sendiri di PC atau laptopnya. Software ini juga berlisensi GNU dan dapat didownload secara gratis di internet mengingat peran vital yang dimilikinya terutama bagi pembuat web pemula (Hermawan, 2019).

\section{METODE PENELITIAN}

\section{A. Alat dan Bahan}

Alat dan bahan yang akan digunakan dalam penelitian Sistem Informasi ini sebagai berikut:

1. Alat

Alat yang digunakan di dalam penelitian adalah:
a. Komputer
b. Printer
c. Database MySQL Server
d. XAMPP
e. Sublime Text 3
f. Browser Goggle Chrome
g. Framework Laravel

\section{Bahan}

Bahan yang digunakan untuk perancangan aplikasi Penjadwalan Ibadah ini adalah sebagai berikut:

a. Data jadwal ibadah Gereja Hebron Protestan Samarinda.

b. Data anggota jemaat di sektor gereja Hebron Protestan Samarinda.

c. Alamat rumah jemaat tempat ibadah di bagian sektor Gereja Hebron Protestan Samarinda berlangsung. 


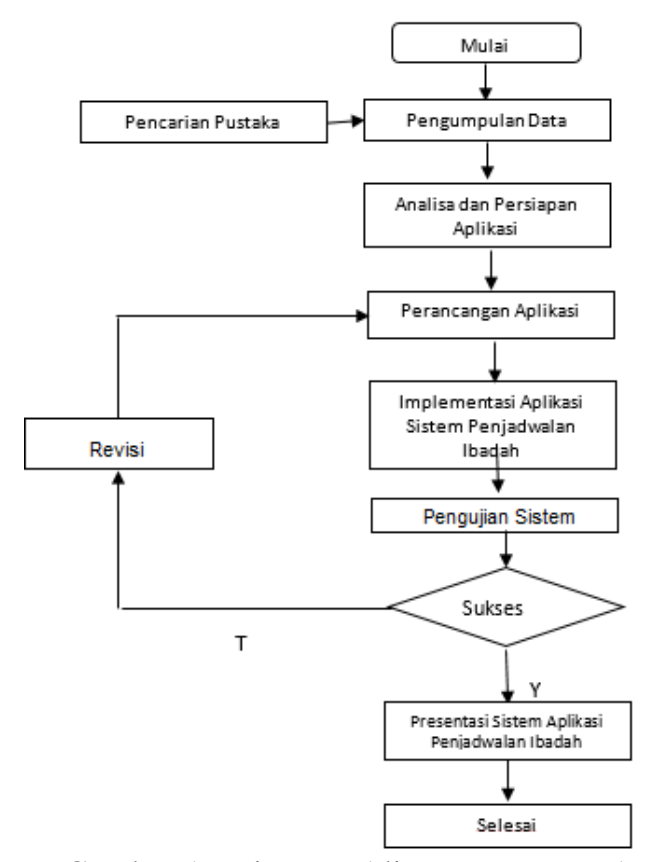

Gambar 1. Diagram Alir Perancangan Aplikasi

\section{Prosedur Penelitian}

1. Diagram Alir Perancangan Aplikasi

Diagram alir perancangan aplikasi. Dapat di lihat pada gambar 1.

Gambar 1. Diagram Alir Perancangan Aplikasi

Penjelasan tentang diagram alur perancangan aplikasi adalah sebagai berikut:

a. Pengumpulan Data

Proses pengumpulan data dilakukan dengan memberi surat kepada bagian Gereja Hebron Protestan Samarinda untuk mendapatkan data gereja, data pelayan serta jadwal ibadah setiap minggunya, kemudian data tersebut diclearing dan divalidasi untuk diolah pada tahap selanjutnya.

b. Analisa dan Persiapan Aplikasi

Sebelum melakukan perancangan aplikasi diperlukan analisa dan persiapan aplikasi meliputi komponenkomponen yang dibutuhkan dalam pembuatan sistem aplikasi penjadwalan ibadah dan jemaat yang menggunakan aplikasi tersebut.

c. Perancangan Aplikasi

Membuat rancangan database menggunakan DFD (Data Flow Diagram). Rancangan aplikasi Data Flow Diagram perancangan aplikasi dapat di lihat pada gambar 2.

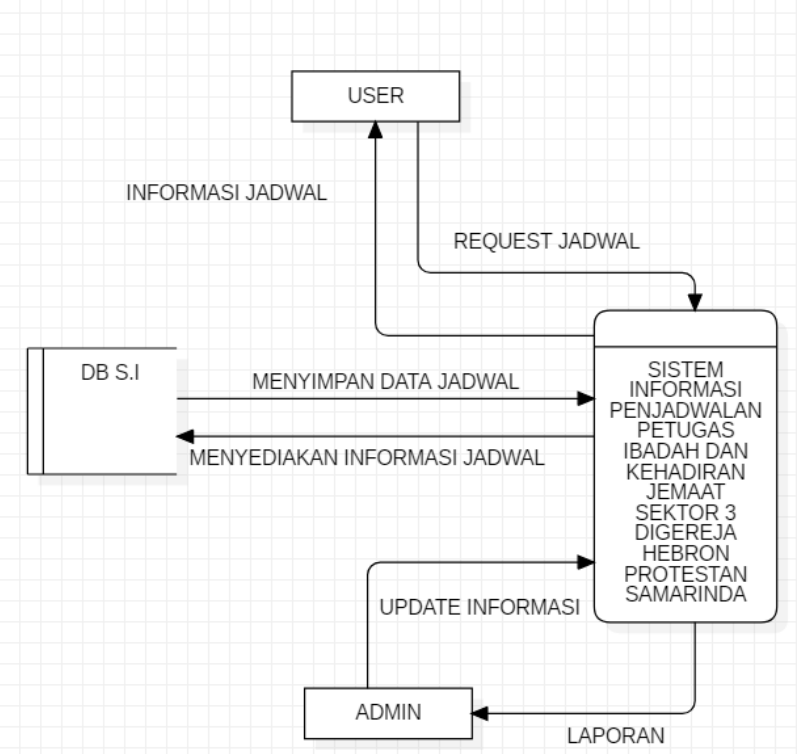

Gambar 2. Data Flow Diagram Level 0

d. Implementasi Sistem Aplikasi Penjadwalan Ibadah.

Dari hasil perancangan aplikasi di atas kemudian dibuat implementasi sistem. Model ERD (Entity relationship Diagram) menjadi database MySQL, kemudian dari rancangan UML (Unified Modeling Language) di implementasikan menjadi aplikasi Penjadwalan Ibadah dan web service yang di bangun dengan Laravel. Implementasi sistem aplikasi dapat di lihat pada gambar 3 .

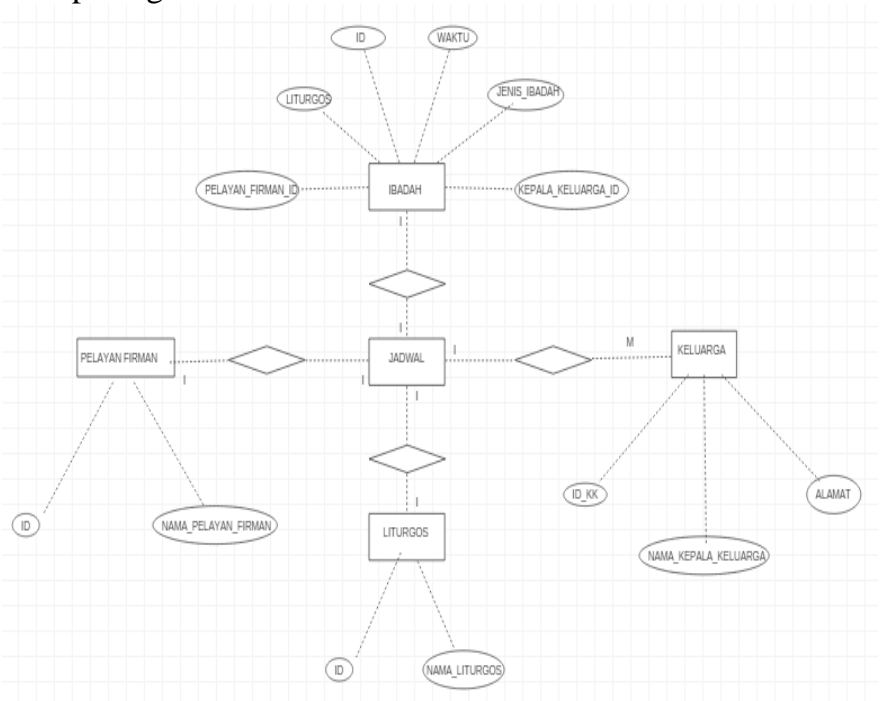

Gambar 3. Entity relationship Diagram Penjadwalan Ibadah

e. Pengujian Sistem

Pada tahap pengujian sistem yaitu untuk mengetahui apakah sistem berjalan dengan baik atau tidak baik, jika ada masalah pada sistem maka akan dilakukan perancangan sistem ulang untuk memperbaiki permasalahan yang ada. 


\section{HASIL DAN PEMBAHASAN}

\section{A. Hasil}

Sistem informasi penjadwalan petugas ibadah dan kehadiran jemaat sektor 3 di Gereja Hebron Protestan Samarinda berbasis web dibuat dengan menggunakan bahasa pemrograman php framework laravel 5.8 dan database menggunakan mysql, Sistem Informasi ini dapat menampilkan jadwal per minggunya dalam 1 bulan dan pendataan jemaat yang hadir pada saat ibadah pelayanan kategori tersebut.

1. Tampilan user merupakan menu yang dapat di akses oleh semua pengguna, Tampilan ini terdiri lebih dari 5 menu utama yang saling terhubung. Dapat dilihat pada gambar 26 di bawah.

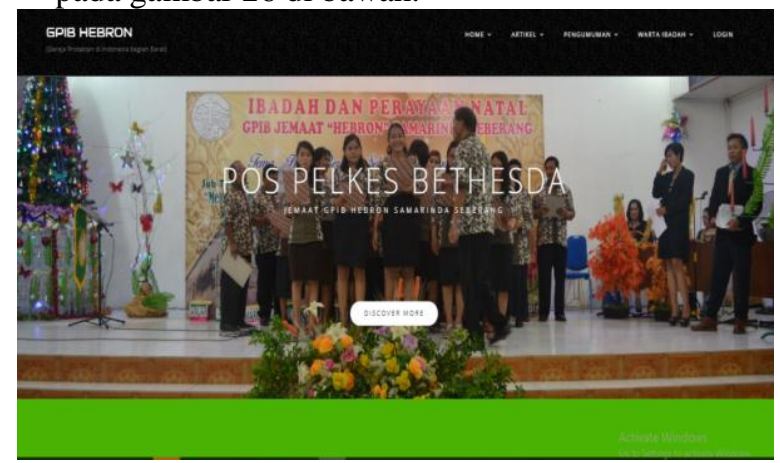

Gambar 4. Tampilan User

2. Halaman pengumunan merupakan tampilan yang memberikan informasi bulan kelahiran jemaat sektor 3. Dapat dilihat pada gambar 29.

\section{GPIB HEBRON}

Bulan Kelahiran

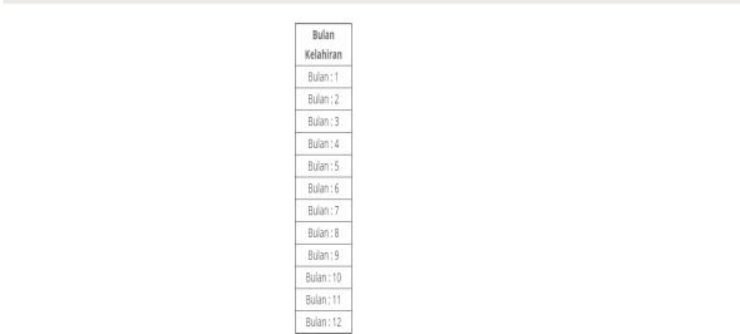

Gambar 5. Tampilan Bulan Kelahiran

3. Halaman warta ibadah ini merupakan tampilan yang menampilkan jadwal ibadah per pelkat yang dimana di dalamnya terdiri dari 4 pelkat yaitu PKB (persekutuan kaum bapa), PKLU (persekutuan kaum lanjut usia), PKP (persekutuan kaum perempuan), dan GP (gerakan pemuda). Yang di jadwalankan 4 kali dalam 1 bulannya. Dapat dilihat pada gambar 31 di bawah.

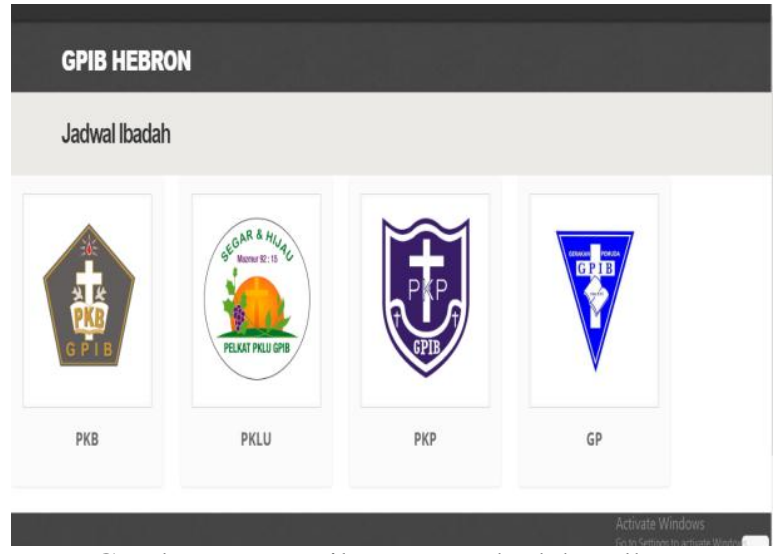

Gambar 6. Tampilan Warta Ibadah Pelkat

4. Pada halaman ini jemaat dapat melihat jadwal tempat ibadah, petugas ibadah dan waktu ibadah tersebut. Dapat dilihat pada gambar 32 di bawah.

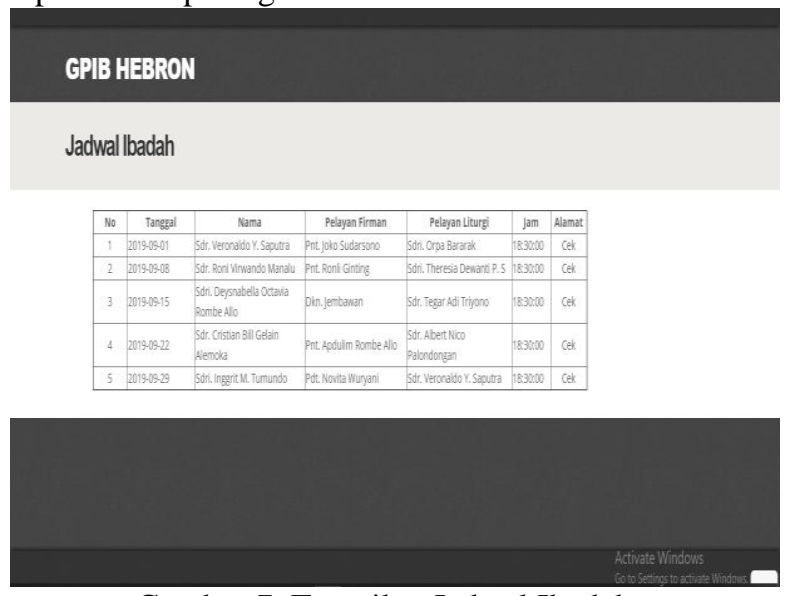

Gambar 7. Tampilan Jadwal Ibadah

5. Pada halaman ini user akan melihat alamat rumah ibadah lebih jelas dan menemukan titik lokasi ibadah yang sudah di tentukan. Dapat di lihat pada gambar 33 di bawah.

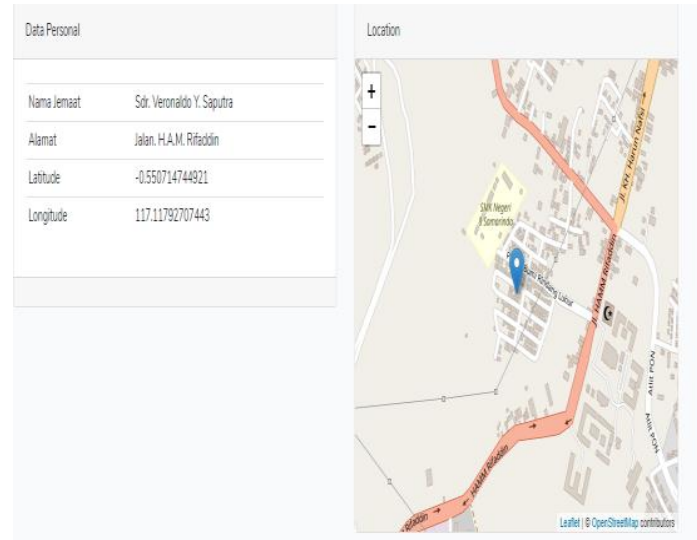

Gambar 8. Tampilan Alamat Tempat Ibadah

\section{B. Pembahasan}

\section{Source Code}

a. Function pengelompokan data keluarga berdasarkan kepala keluarga

Function ini dibuat untuk memanggil relasi one to many berdasarkan id tabel head, yang bertujuan untuk 
pengelompokan anggota keluarga berdasarkan kepala keluarga pada form input.

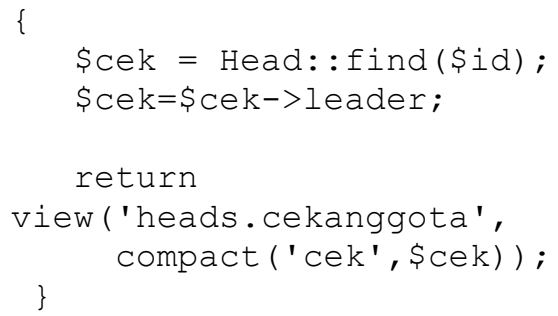

b. Cek alamat user di dalam maps berdasarkan id

Function ini dibuat untuk melihat alamat users berdasarkan inputan alamat letak longitude dan latitude pada maps.

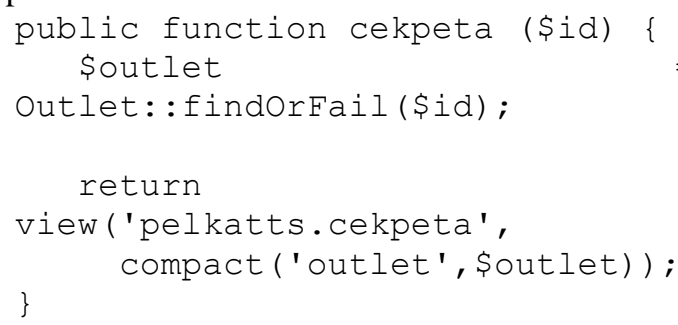

c. Menampilkan data pelkat

Function ini dibuat untuk menampilkan seluruh data tabel pelkat.

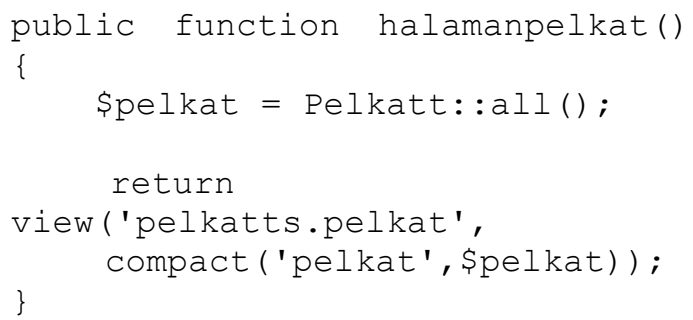

d. Pengelompokan jadwal ibadah yang berisi user

Function ini dibuat untuk mengelompokan data jemaat berdasarkan jadwal ibadah per pelkat.

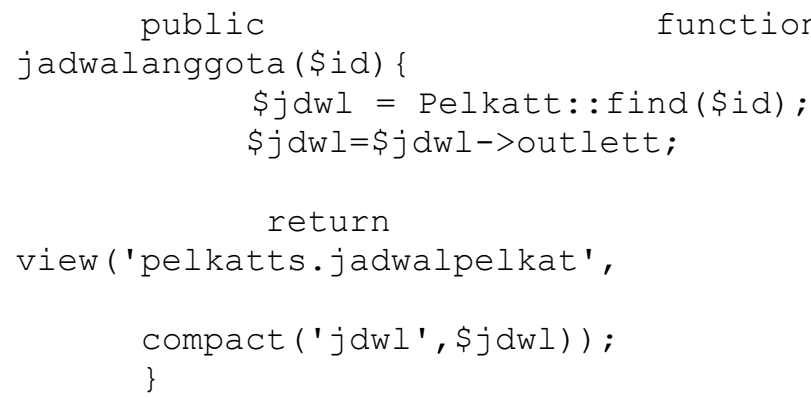

e. Download file word lembar katekisasi

Function ini berfungsi untuk download file berekstensi pdf pada folder public.

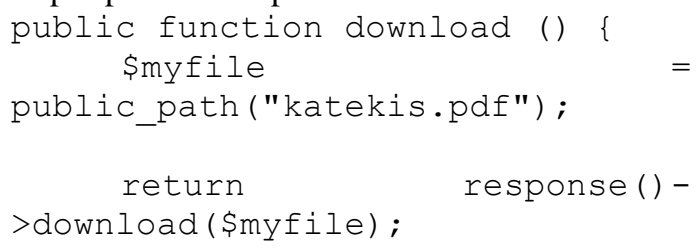

\section{\}}

Halaman maps

Function ini menampilkan letak titik koordinat alamat jemaat secara keseluruhan.

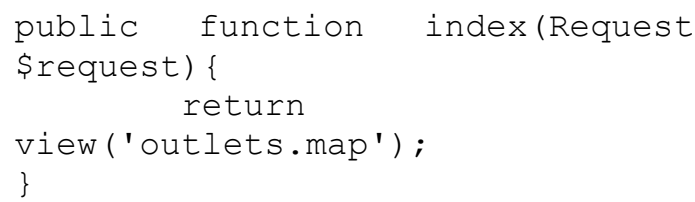

g. Pemanggilan maps leaflet

Source code ini untuk pemanggilan fungsi js leaflet, marker, longitude dan latitude titik koordinat saat user input alamat.

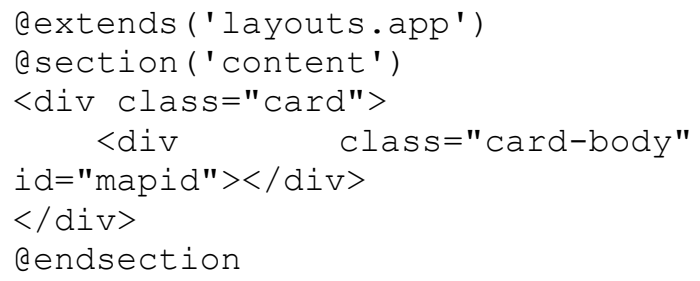


L.tileLayer('https://\{s\}.tile.op enstreetmap.org/ $\{\mathrm{z}\} /\{\mathrm{x}\} /\{\mathrm{y}\}$.png' ,\{

$$
\text { attribution: '\&copy; <a }
$$

href="https: //www. openstreetmap. org/copyright" >openStreetMap $</ a>$ contributors'

\}) . $\operatorname{addTo}(\operatorname{map})$;

axios.get ( ' $\{$ \{

route ('api.outlets.index') \} \}')

.then (function (response) \{

console. log (response.data); L.geoJSON (response.data, \{

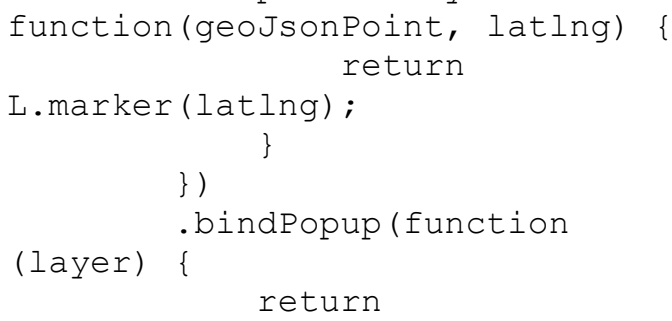

theMarker

L.marker ( [latitude,

longitude]).addTo (map);

theMarker.bindPopup (popupContent )

. openPopup ( ) ;

\});

dendcan

@endpush

$$
</ \text { script }>
$$

\section{KESIMPULAN}

Sistem Informasi Penjadwalan Petugas Ibadah dan Kehadiran jemaat Sektor 3 di Gereja Hebron Protestan Samarinda Berbasis Web dengan PHP framework laravel ini telah berhasil dikembangkan, sistem ini mampu menampilkan jadwal ibadah per pelkat dan mendata jemaat yang hadir, download pendaftaran katekisasi, dan pengumuman-pengumuman tiap bulannya.

Dalam penelitian ini tentunya masih terdapat banyak kekurangan dan hal-hal yang masih perlu dikaji dan dikembangkan kembali. Peneliti memiliki pemikiran dan saran untuk pengembangan kedepan antara lain, dapat di kembangkan Sistem Informasi Penjadwalan Petugas Ibadah dan Kehadiran jemaat Sektor 3 di Gereja Hebron Protestan Samarinda dengan notifikasi jadwal melalui SMS Gateway yang tersambung oleh database, sistem Informasi Penjadwalan Petugas Ibadah dan Kehadiran Jemaat Sektor 3 di Gereja Hebron Protestan Samarinda dapat melakukan pendaftaran Jemaat baru, sistem Informasi Penjadwalan Petugas Ibadah dan Kehadiran jemaat Sektor 3 di Gereja Hebron Protestan Samarinda dapat di implementasikan ke platform android.

\section{DAFTAR PUSTAKA}

Anindya. (2017). PERANCANGAN SISTEM INFORMASI TEMPAT IBADAH BERAGAM. Diambil kembali dari eprints.ums: http://eprints.ums.ac.id/49213/1/naskah\%20publikasi .pdf.

Dimas. (2016, 6 24). Pengertian SI (SISTEM INFORMASI). Diambil kembali dari kompasiana: https://www.kompasiana.com/dimasosd/55291077f1 7e6126268b48b6/pengertian-si-sistem-informasi.

Giovanny. (2014). PRIORITAS SEORANG PELAYAN TUHAN. Diambil kembali dari holytrinitycarmel: http://www.holytrinitycarmel.com/prioritas-seorang pelayan-tuhan/.

Hermawan. (2019, 5 29). Pengertian MySQL Beserta Fungsi dan Sejarah Terbentuknya MySQL Secara Lengkap. Diambil kembali dari nesabamedia: https://www.nesabamedia.com/pengertian-mysql/.

Ica. (2019, 1 8). Pengertian dan Keunggulan Frame work Laravel. Diambil kembali dari inditek.id: https: //inditek.id/pengertian-dan-keunggulan-frameworklaravel. 
Ircham, A. (2017). Sistem Informasi Penjadwalan Pelatihan Divisi Training Seamolec Berbasis Web. Diambil kembali dari researchgate:https://www.researchgate.net/publicatio n/312215413_Sistem_Informasi_Penjadwalan_Pelati han_Divisi_Training_Seamolec_Berbasis_Web.

Iskandar, A. K. (2006). Penulis Literatur dan Umum PELITAKU. Diambil kembali dari pelitaku.sabda.org: http://pelitaku.sabda.org/liturgis_vs_liturgos.

Jenius. (2012). Pengertian , Fungsi, dan Contoh Data Flow Diagram. Diambil kembali dari 7enius.wordpress: https://7enius.wordpress.com/2012/03/11/pengertianfungsi-dan-contoh-dari-data-flow-diagramdfd/.

Kemala. (2019, 12 6). Pengertian Teknologi Informasi, Serta Tujuan dan Fungsinya. Diambil kembali dari teknologi.id: https://teknologi.id/insight/pengertianteknologi-informasi-serta-tujuan-dan-fungsinya/.

N, S. (2015, 9 24). Pengertian UML Dan Jenis-Jenisnya Serta Contoh Diagramnya. Diambil kembali daripengertianku.net:http://www.pengertianku.net/20 15/09/pengertian-uml-dan-jenis-jenisnya-sertacontoh-diagramnya.html.

Nauli, S. B. (2017, 5 1). Perancangan Situs Web Untuk Informasi. Diambil kembali dari teknik.usni.ac.id:https://teknik.usni.ac.id/jurnal/suka rno.pdf.

Novitasari, A. D. (2017). Perancangan Sistem Informasi Tempat Ibadah Beragam. Diambil kembali dari eprints.ums:

http://eprints.ums.ac.id/49213/1/naskah\%20publika si.pdf.

Nurmiati, S. (2017). Sistem Informasi Penjadwalan Fasilitas Berbasis Web Studi Kasus Pada Institut Sains Dan Teknologi Nasional2017. Diambil kembali dari journal.uta45jakarta: http://journal.uta45jakarta.ac.id/index.php/JKTE/art icle/view/551.

Syafitri, I. (2019, 6 29). Pengertian PHP Beserta Fungsi dan Sejarah PHP yang Wajib Anda Ketahui. Diambil kembali dari nesabamedia: https://www.nesabamedia.com/pengertian-php-danfungsinya/.

Syani, M. (2017, 1). Sistem informasi penjadwalan pelatihan divisi training seamolec berbasis web. Diambil kembali dari researchgate.net: https://www.researchgate.net/publication/31221541 3_sistem_informasi_penjadwalan_pelatihan_divisi_ training_seamolec_berbasis_web. 